\title{
Elaboration of wide bandgap CIGS on silicon by electrodeposition of stacked metal precursors and sulfur annealing for tandem solar cell applications
}

\author{
Alexandre Crossay ${ }^{1, *}$, Davide Cammilleri ${ }^{1}$, Angelica Thomere ${ }^{2}$, Bienlo Zerbo ${ }^{1,3}$, Amelle Rebai ${ }^{4}$, Nicolas Barreau $^{2}$, \\ and Daniel Lincot ${ }^{1,4}$ \\ ${ }^{1}$ Institut Photovoltaïque d'Ile-de-France (IPVF), 18 Boulevard Thomas Gobert, 91120 Palaiseau, France \\ ${ }^{2}$ Université de Nantes, CNRS, Institut des Matériaux Jean Rouxel, IMN, 2 Chemin de la Houssinière, 44300 Nantes, France \\ ${ }^{3}$ Faculté des Sciences d'Orsay, Université Paris Saclay, 15 rue Georges Clémenceau, 91400 Orsay cedex, France \\ ${ }^{4}$ CNRS UMR 9006 IPVF, 18 Boulevard Thomas Gobert, 91120 Palaiseau, France
}

Received: 25 August 2020 / Received in final form: 29 October 2020 / Accepted: 30 November 2020

\begin{abstract}
A method was developed for the electrodeposition of $\mathrm{Cu}$-In-Ga precursor layers to elaborate $\mathrm{Cu}(\mathrm{In}, \mathrm{Ga})(\mathrm{S}, \mathrm{Se})_{2}$ (CIGS) thin films on silicon substrates for future application as silicon/wide-gap CIGS tandem solar cells. An underlayer of Ag was first deposited on silicon substrates to ensure a good adhesion of the electrodeposited stack and to serve as cathode during the deposition process. $\mathrm{Cu}$, In and Ga layers were then sequentially electrodeposited. Ag-Cu-In-Ga precursor layers were finally subjected to elemental sulfur annealing at $600^{\circ} \mathrm{C}$. Formation of compact and adherent AgCIGS is observed. X ray diffraction and photoluminescence analyses confirm the formation of wide-gap CIGS of about $1.6 \mathrm{eV}$, with a spontaneous gallium grading over the depth of the sample leading to the formation of a bi-layer structure with a gallium rich layer at the interface with silicon.
\end{abstract}

Keywords: Tandem solar cells / pure sulfide CIGS / silicon / electrodeposition / silver-sulfide

\section{Introduction}

$\mathrm{Cu}(\mathrm{In}, \mathrm{Ga})(\mathrm{S}, \mathrm{Se})_{2}$ (CIGS) is a good candidate for tandem solar cell applications thanks to the tunability of its bandgap, modified by changing the ratios $\mathrm{In} / \mathrm{Ga}$ and $\mathrm{Se} / \mathrm{S}$. In particular, wide-gap CIGS can be efficiently combined with silicon in tandem solar cells, the CIGS acting as the top semi-transparent solar cell. Pure sulfide $1.55 \mathrm{eV}$ $\mathrm{Cu}(\mathrm{In}, \mathrm{Ga}) \mathrm{S}_{2}$ (CIGSu) already reached efficiencies of $16.9 \%$ via a two-step route consisting of the deposition of metals followed by a reactive sulfur annealing $[1,2]$. Barreau et al. also recently reported a $14.2 \%$ pure sulfide solar cell deposited by coevaporation for a bandgap of about $1.65 \mathrm{eV}$ [3], together with an extensive study of the pure sulfide CIGS system [4]. Bandgap engineering and efficiency improvement can also be achieved by partial substitution of copper by silver [5]. Recent investigations on $(\mathrm{Ag}, \mathrm{Cu})$ (In, Ga) $\mathrm{Se}_{2}$ led to a $15.1 \%$ efficiency solar cell with a wide bandgap of $1.45 \mathrm{eV} \mathrm{[6]} \mathrm{and} \mathrm{to} \mathrm{a} 20.6 \%$ solar cell [7].

\footnotetext{
* e-mail: alexandre.crossay@cnrs.fr
}

A simulation of silicon/CIGS tandem solar cell was published [8], showing the possibilities for achieving high efficiencies. From the experimental point of view there are only few studies available. One can mention the achievement of a $9.7 \%$ silicon/CuGaSe ${ }_{2}$ tandem solar cell with monolithic integration [9]. The interface configuration is based on the deposition of a recombination layer of ITO between the silicon and the CIGS. A recent study shows the proof of concept of a monolithic Si/CZTS tandem [10]. The interesting point is that the recombination layer at the interface consists in a titanium nitride layer on a TOPCon Si bottom cell. This layer also provides an efficient diffusion barrier for copper during the high temperature deposition of CZTS. Our approach is to use a silicon $n+/ p+$ tunnel junction at the top of a silicon bottom cell as shown in a recent paper by Fave et al. [11].

The fabrication process of CIGS for single-junction solar cells has been widely studied, mostly to prepare narrow-gap selenide or seleno-sulfide CIGS, and a record efficiency of $23.35 \%$ was achieved by a two-step vacuum process [12]. Non-vacuum deposition processes have also been investigated, including electrodeposition which offers the advantages of being a fast and easily upscalable 
process. An efficiency of $11.3 \%$ was obtained in 2004 with a band gap of $1.45 \mathrm{eV}$ [13] via co-electrodeposition of CISe and sulfur annealing. Moreover, the Nexcis company recently reported both a $17.3 \%$ efficient cell and a $14 \%$ $60 \times 120 \mathrm{~cm}^{2}$ module [14,15] via electrodeposition of stacks $\mathrm{Cu} / \mathrm{In} / \mathrm{Ga}$ and selenization. These results were obtained by depositing CIGS on a classical glass/molybdenum substrate. Co-electrodeposition of pure selenide CIGS on silicon was reported by Saïdi et al. [16], however the films porosity limited the cells efficiencies to $3.8 \%$. Less effort has been devoted to the study of pure sulfide CIGS, however very promising results were already achieved by Solar Frontier [2] and IMN [3] as discussed previously.

In this context, we report on the development of a process to prepare dense and adherent AgCIGSu layers on silicon by sequential electrodeposition of $\mathrm{Cu}$, In and $\mathrm{Ga}$ and sulfurization, via the incorporation of an evaporated $\mathrm{Ag}$ layer between the silicon substrate and the $\mathrm{Cu} / \mathrm{In} / \mathrm{Ga}$ stack.

\section{Experimental}

AgCIGSu thin films on silicon were obtained via a two-step process, with the deposition of a metallic $\mathrm{Ag}-\mathrm{Cu}-\mathrm{In}-\mathrm{Ga}$ precursor on a silicon substrate, followed by a sulfurization at high temperature.

The Silicon substrates used for this study were (100) p-type doped Si wafers, etched for $30 \mathrm{~s}$ in a $5 \%$ HF solution. A $50 \mathrm{~nm}$ thick silver layer was deposited by evaporation at a rate of $0.1 \mathrm{~nm} / \mathrm{s}$ on a surface of $25 \mathrm{~cm}^{2}$. Si $/ \mathrm{Ag}$ samples were etched in $1 \mathrm{M} \mathrm{NH} \mathrm{NH}_{3}$ for $3 \mathrm{~min}$, followed by the deposition of $\mathrm{Cu}$, In and Ga.

Copper, indium and gallium were sequentially electrodeposited on $\mathrm{Si} / \mathrm{Ag}$. Metals were deposited from commercially available aqueous electrolytes at high rates of $200-300 \mathrm{~nm} / \mathrm{min}$. The deposition was performed in a three-electrode setup with a mercury sulfate reference electrode (MSE), allowing to record the variation of the layer electrochemical potential throughout the process. Copper, indium and gallium were deposited under intentiostatic conditions at current densities of $12 \mathrm{~mA} / \mathrm{cm}^{2}$ according to the following global electrochemical reactions:

$-\mathrm{Cu}(\mathrm{II})+2 \mathrm{e}^{-} \rightarrow \mathrm{Cu}(0)$

$-\mathrm{In}(\mathrm{III})+3 \mathrm{e}^{-} \rightarrow \operatorname{In}(0)$

$-\mathrm{Ga}(\mathrm{III})+3 \mathrm{e}^{-} \rightarrow \mathrm{Ga}(0)$.

Copper was electrodeposited from an acidic $\mathrm{OMNiCu}$ electrolyte from the commercial supplier KMG Ultrapure Chemicals SAS ( $\mathrm{pH} 0.9$ ). Indium was deposited from an Heliofab In 390 basic electrolyte from MacDermid Enthone (pH 10). Gallium was deposited from an Heliofab Ga 365 basic electrolyte from MacDermid Enthone (pH 13.6). The time needed to deposit a given thickness is calculated by Faraday's first law of electrolysis, corrected for each metal with its faradaic efficiency. This model accounts for parallel cathodic reactions that do not directly contribute to the metals reduction, such as hydrogen formation. The films composition can then be easily tuned by varying the deposition time for each layer. All electrodepositions were done under ambient atmosphere, at room temperature under mechanical stirring in the electrolyte.

$\mathrm{Si} / \mathrm{Ag}-\mathrm{Cu}-\mathrm{In}-\mathrm{Ga}$ precursors were annealed in a tubular furnace at $600{ }^{\circ} \mathrm{C}$ during $10 \mathrm{~min}$ in a graphite box containing $60 \mathrm{mg}$ of elemental sulfur powder, under flowing nitrogen at atmospheric pressure. The heating rate was fixed at $40^{\circ} \mathrm{C} / \mathrm{min}$, and the oven was left to cool down naturally, which typically takes about $3-4 \mathrm{~h}$.

Scanning electron microscope (SEM) pictures and energy-dispersive X-ray (EDX) spectra were taken with a Zeiss Merlin compact microscope. The compositions of sulfurized films were measured by EDX on their crosssection. Microcrystalline structure of the layers was analyzed by X-ray diffraction (XRD) on a PANalytical - DY711 with $\mathrm{Cu}$ K $\alpha$ radiation. Composition profiles were measured by glow discharge optical emission spectroscopy (GDOES) using a Horiba GD Profiler 2. Raw GDOES intensities are non-quantitative, and were either normalized (Fig. 2a) or corrected with the global composition of the AgCIGS film (Fig. 3d). For the latter, the raw signals of $\mathrm{Cu}, \mathrm{Ag}, \mathrm{In}, \mathrm{Ga}$ and $\mathrm{S}$ were divided by their average value over the whole AgCIGS film (between 0 and $180 \mathrm{~s}$ sputtering time) and multiplied by the atomic percentage of the element in the layer. The Si raw GDOES signal was simply multiplied by 80 to reach at maximum an arbitrary value of 55. Photo-luminescence analyses were performed using a Horiba Labram HR with an excitation wavelength of $532 \mathrm{~nm}$.

\section{Results and discussion}

\subsection{Deposition of metallic precursor}

The aim of this study is to develop an efficient route to synthesize CIGS on silicon substrates. To this end, direct electrodeposition of $\mathrm{Cu} / \mathrm{In} / \mathrm{Ga}$ stacks on silicon was first attempted. While smooth and dense layers of copper were obtained, the indium deposition required a large electrodeposition overpotential ( $-3 \mathrm{~V}$ vs. MSE), causing a strong hydrogen formation and subsequent delamination of the weakly adherent copper layer on Silicon. To circumvent this effect, a different approach was developed, consisting of depositing a $50 \mathrm{~nm}$ layer of silver by evaporation on the silicon's surface. This intermediate layer offers two direct advantages, (i) the adhesion of silver on silicon is greatly improved compared to electrodeposited copper on silicon, and (ii) its sheet resistance is estimated at $0.32 \Omega / \square$, which is sufficiently low to avoid passing the electrodeposition current through the silicon solar cell and to prevent voltage drops across the substrate's surface. $\mathrm{Cu}$, In and Ga metallic layers depositions further decrease the sheet resistance value. Furthermore, silver has been used as a contact on silicon solar cells for more than three decades [17] and thus should act as a protective layer at least as long as the sulfurization or alloying with other metals does not occur.

The sequential electrodeposition of $\mathrm{Cu}$, In and $\mathrm{Ga}$ on silver is presented on Figure 1a, showing the evolution of deposition potentials for each step. For all three metals, the deposition potential rapidly reaches the steady-state values of $-0.76 \mathrm{~V}$ vs. MSE for $\mathrm{Cu},-3 \mathrm{~V}$ for In and $-2.4 \mathrm{~V}$ for Ga, showing an excellent stability of the deposition process. 

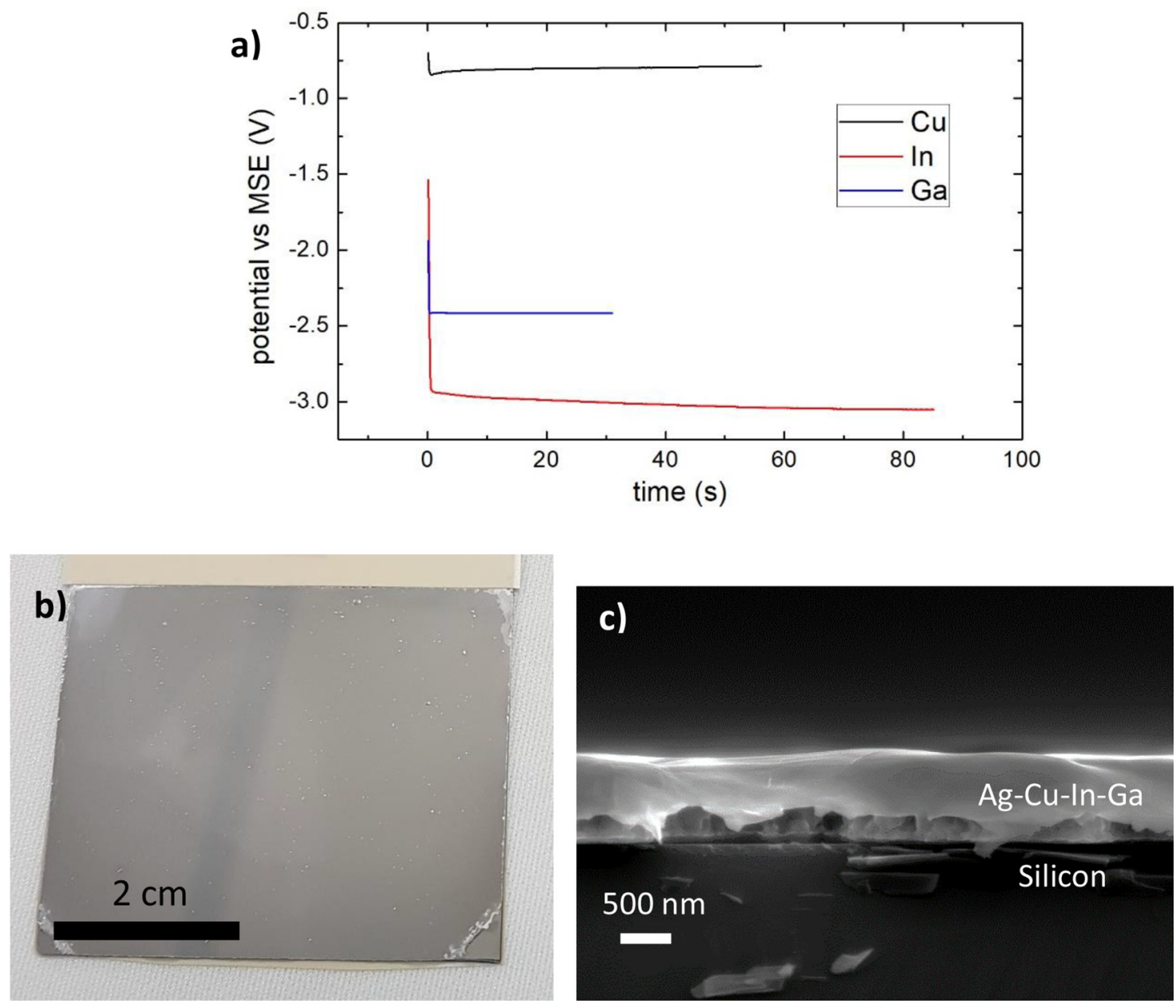

Fig. 1. (a) Electrodeposition potentials (vs. MSE reference electrode) on a $20 \mathrm{~cm}^{2}$ sample for fixed current densities of $12 \mathrm{~mA} / \mathrm{cm}^{2}$; (b) photograph of a $4 \mathrm{~cm} \times 5 \mathrm{~cm}$ electrodeposited stack $\mathrm{Cu} / \mathrm{In} / \mathrm{Ga}$ on $\mathrm{Si} / \mathrm{Ag}$; (c) SEM cross-section image of a stack, four days after deposition.

The deposition times were fixed to achieve the CIGS composition required for high photovoltaic performances. The global chemical composition of CIGS is expressed as $\mathrm{Cu}_{x} \mathrm{In}_{1-y} \mathrm{Ga}_{\mathrm{y}} \mathrm{S}_{2+z}$ where $x=1, z=0$ and $y$ is ranging from 0 to 1 for stoichiometric composition. These parameters are conveniently expressed as two ratios, $\mathrm{Cu}$ to $(\mathrm{In}+\mathrm{Ga})$ and Ga to $(\mathrm{In}+\mathrm{Ga})$ named as CGI and GGI respectively. Best efficiencies reported in the literature are obtained both for selenides or sulfides with CGI $<1(0.8-1)$ and GGI about 0.3 . The experiments were thus designed to achieve these targets. In case of silver alloying, $\mathrm{Cu}$ content is replaced by $(\mathrm{Cu}+\mathrm{Ag})$. A $1.8 \mu \mathrm{m}$ thick AgCIGS film requires the deposition of $50 \mathrm{~nm}$ of silver, $190 \mathrm{~nm}$ of copper, $365 \mathrm{~nm}$ of indium and $118 \mathrm{~nm}$ of gallium for GGI $=0.3$ and CGI of 0.95 . The plating efficiencies measured for this process were of $0.73,0.59$ and 0.69 for respectively $\mathrm{Cu}$, In and Ga. The complete electrodeposition of $\mathrm{Cu}$, In and Ga takes less than 3 min thanks to the use of concentrated electrolytes. Macroscopic and microscopic images of the final layers on Figures $1 \mathrm{~b}$ and $1 \mathrm{c}$ show that dense, smooth and adherent precursors are obtained. Two distinctive layers are observed on top of the silicon substrate (Fig. 1c), the bottom one is well crystallized whereas the top layer seems more amorphous and very ductile. The very rough interface between these two layers is most probably due to the high ductility of the top layer, causing it to extend during the breaking process for the preparation of the cross section. The top layer is thus protruding and partially hiding the bottom layer on the image of Figure 1c.

Although all layers were deposited at room temperature, a very strong re-organization of the metals' distribution is observed four days after their preparation, as seen on the composition profiles of Figure 2a. Most of the indium appears to have diffused towards the surface, leaving copper and gallium at the back of the film. A thin surface layer of gallium is observed, most probably due to the quick formation of an oxide layer after the electrodeposition of gallium. XRD analyzes of Figure $2 \mathrm{~b}$ confirm these observations, with the presence of strong indium phase peaks, and smaller peaks of $\mathrm{Cu}$ and $\mathrm{CuGa}_{2}$. These observations are very similar to previous results by Oliva [18], who also describes an accumulation of most of the indium at the surface of the thin film after electrodeposition of $\mathrm{Cu} / \mathrm{In} / \mathrm{Ga}$ stacks onto glass/Mo substrates. The same 

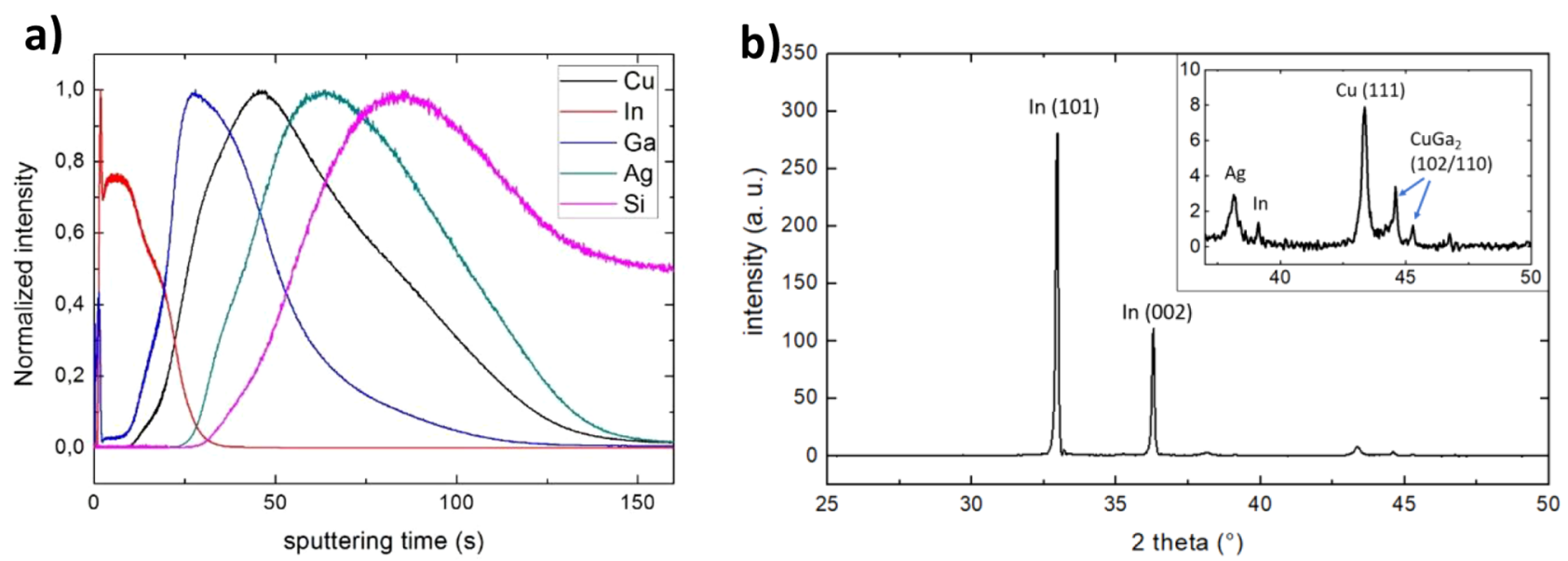

Fig. 2. (a) Composition profile analysis by GDOES and (b) XRD pattern of Ag-Cu-In-Ga on silicon four days after electrodeposition showing the redistribution of metallic elements. Inset is a magnification between $37^{\circ}$ and $50^{\circ}$.

XRD peaks were also observed in their study, except for the peaks that we attribute to the silver phase. The silver seems to remain where it was originally deposited, that is, between the $\mathrm{Cu}-\mathrm{In}-\mathrm{Ga}$ and the silicon. XRD analyses of Figure $2 \mathrm{~b}$ also detect a small signal from this silver phase.

The detection of silver between the silicon and the other metals is a very good point, since this metal is supposed not to be harmful for Si solar cells at room temperature as discussed previously. However, the early detection of silicon in the Ag-Cu-In-Ga film (Fig. 2a) raises questions about a possible diffusion process, either of silicon through the deposited metallic film or of metals into the silicon wafer. Another possible explanation could be the presence of In-Ga alloys melting at very low temperature, which could cause de-wetting of the layer during the GDOES ablation process.

We show here that this approach of using an intermediate silver layer to electrodeposit $\mathrm{Cu}$-In-Ga onto silicon is successful. The process is fast, easily upscalable and allows to tune the precursors composition by simply varying the layers' thicknesses, which is fundamental to optimize the fabrication of wide-gap CIGS on silicon.

\subsection{Sulfurized layers on silicon}

The precursors described in the previous section were subjected to a reactive annealing at $600{ }^{\circ} \mathrm{C}$ for $10 \mathrm{~min}$ in presence of sulfur powder. Precursor composition optimizations led to the formation of a thin film of overall composition $\mathrm{Ag} /(\mathrm{Cu}+\mathrm{Ag})=0.1 ;(\mathrm{Ag}+\mathrm{Cu}) /(\mathrm{In}+\mathrm{Ga})=0.95$; $\mathrm{Ga} /(\mathrm{In}+\mathrm{Ga})=0.3$, very close to the target composition for $1.7 \mathrm{eV}$ CIGS. This sample is described in the following.

SEM cross section images of Figures $3 \mathrm{a}$ and $3 \mathrm{~b}$ show a dense film after annealing, with a two-layer structure composed of a bottom film with small grains and a top film with larger grains. EDX mappings and GDOES of the cross section shown on Figures 3a, 3c and 3d indicate a strong gradient of indium, gallium and silver in the depth of the sample. The top layer is composed of an AgCIGSu phase with a very low GGI ratio, with typical large grains, whereas the back layer is mostly composed of small grains of wide-GGI AgCIGSu. XRD measurements of Figure 4 confirm the presence of at least two distinct phases, one being indium-rich and the other gallium-rich. Silver segregates at the front of the film, in the low-GGI AgCIGSu top layer.

The appearance of a significant silicon signal approximately in the middle of the bottom wide-GGI AgCIGSu layer could be due to the roughness of the film, or to the diffusion of silicon into the AgCIGSu film.

XRD analyses of Figure 4 indicate two separate phases, corresponding to the top low-GGI phase and the bottom wide-GGI phase. Detailed analysis of the peaks positions can provide information on substitution of copper atoms by silver and of indium atoms by gallium: the larger radius of silver atoms induces an increase of lattice parameters and consequently decreases the peak position compared to pure $\mathrm{CuInS}_{2}$. The opposite behavior is observed when substituting indium by gallium. The inset of Figure 4 shows the two (112) peaks that are detected between $26.5^{\circ}$ and $30^{\circ}$. The peak at $27.7^{\circ}$ confirms the presence of silver in the low-GGI phase. Assuming a GGI of 0 as indicated by the GDOES data of Figure 3d, a value of $\mathrm{Ag} /(\mathrm{Cu}+\mathrm{Ag})$ around 0.2 is found. The second (112) peak at $28.9^{\circ}$ is attributed to the bottom wide-GGI layer. However, the composition of this phase can not be exactly confirmed by XRD, due to the antagonistic effects of alloying with $\mathrm{Ga}$ and $\mathrm{Ag}$.

A photoluminescence spectrum is presented in Figure 5. It is characterized by a sharp peak centered at $1.52 \mathrm{eV}$ and a smaller peak at a lower energy of about $1.3 \mathrm{eV}$. Several studies address the analysis of luminescence spectra of copper indium gallium sulfide and copper indium sulfide as recalled in a recent paper from Kim et al. [20]. This paper deals with layers formed under copper rich and copper poor conditions. It shows that luminescence spectra of layers formed in copper rich conditions present low energy transitions around $1.35 \mathrm{eV}$ attributed to deep levels, probably $\mathrm{Cu}_{\text {In }}$ and $\mathrm{V}_{\text {In }}$ and high energy transitions at 1.54 and $1.62 \mathrm{eV}$ attributed to band to band transitions. In the case of films grown under copper poor conditions, the deep level contribution at $1.35 \mathrm{eV}$ was suppressed and a 
a)

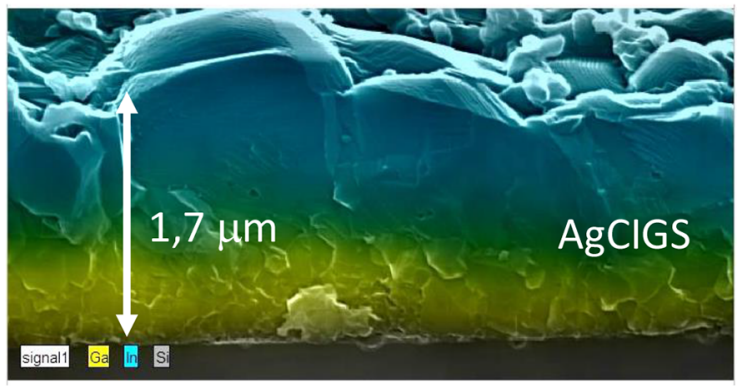

c)

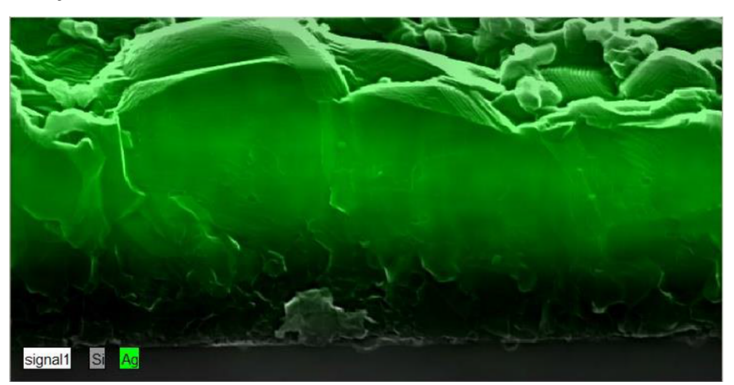

b)

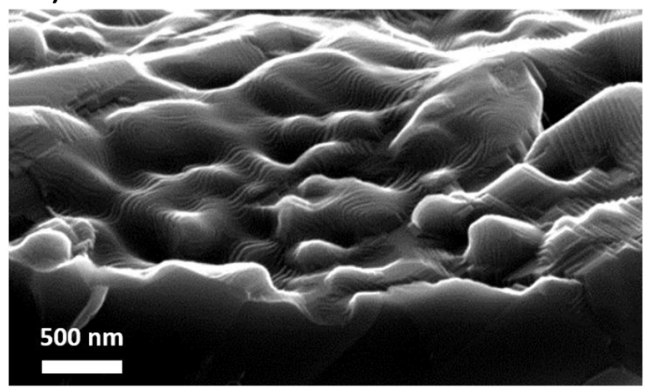

d)

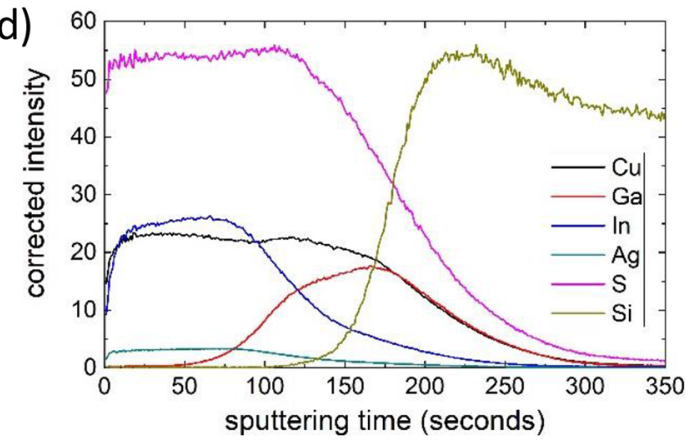

Fig. 3. (a) SEM cross section colorized with EDX intensities of In in blue and Ga in yellow, (b) SEM top view tilted, (c) SEM cross section image colorized with EDX intensity of Ag in green, (d) GDOES analysis of AgCIGSu on silicon. Raw intensities are corrected as described in the experimental section to give an estimation of atomic percentages in the AgCIGS film.

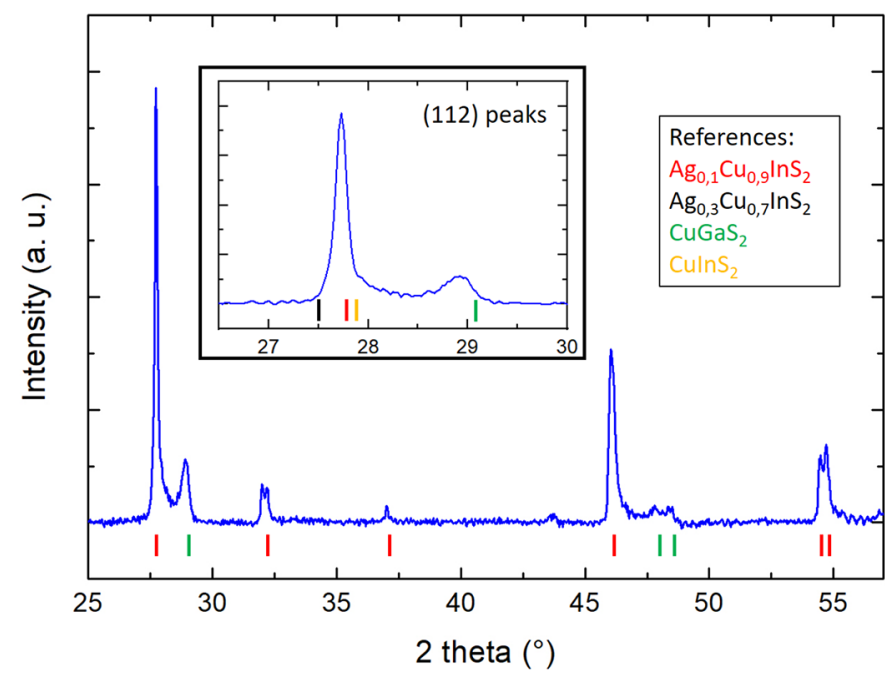

Fig. 4. XRD pattern of $\mathrm{Si} / \mathrm{Ag} / \mathrm{Cu}-\mathrm{In}-\mathrm{Ga}$ sample after $600^{\circ} \mathrm{C}$ sulfurization. Inset is a magnification between $26.5^{\circ}$ and $30^{\circ}$. References are taken from [19].

band to band transition maintained at $1.53 \mathrm{eV}$. These films were associated to a better PV quality. In the previous study by Barreau et al. on CIGSu films prepared by coevaporation [3], similar trends were observed, with a decrease of the deep level peak when the deposition temperature was increased. In our case we observe similar luminescence spectra and can attribute the high energy

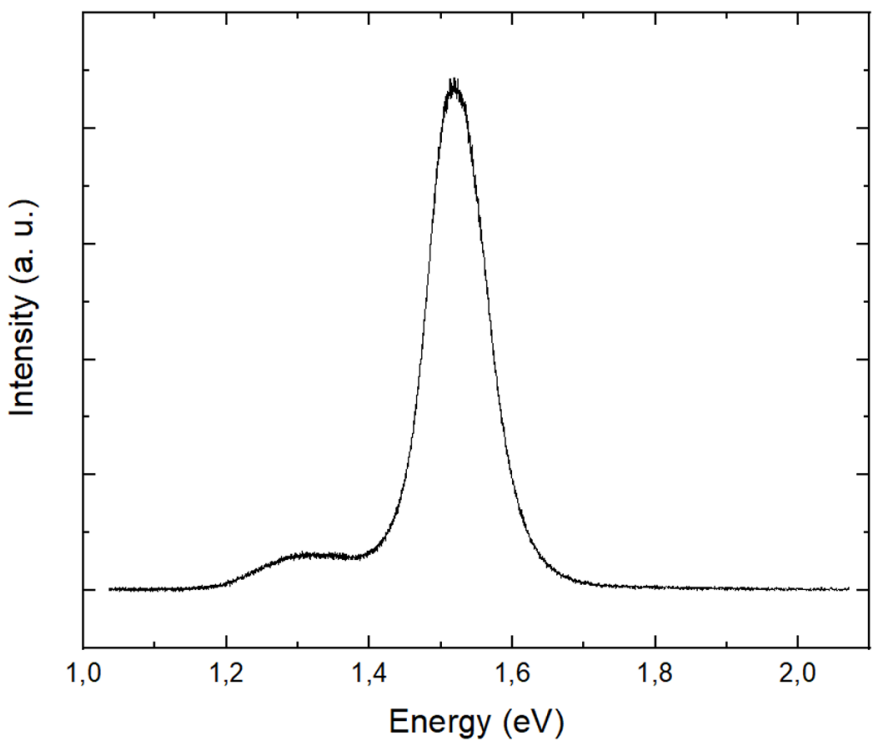

Fig. 5. Photoluminescence spectrum of $\mathrm{Si} / \mathrm{Ag} / \mathrm{Cu}-\mathrm{In}-\mathrm{Ga}$ sample after $600{ }^{\circ} \mathrm{C}$ sulfurization.

peak to band to band, or shallow level to band transitions [20] in the top layer with a low GGI, and the lower energy peak to similar deep levels.

Spontaneous in-depth GGI grading has already been reported during the sulfurization of metallic precursors on glass/Mo by Hiroi et al. [21], and was shown to be beneficial for the cells performances, thanks to bandgap grading 
which could improve electron-hole separation by accelerating the drift of electrons toward the space charge region and prevent back contact recombination. The previously mentioned publication of Kim et al. [20] also reports the formation of a gallium gradient. A similar effect was observed as well by Barreau et al. [3] in the case of a coevaporated CIGSu layer on glass/Mo substrates showing that it is a fundamental trend in sulfides. The corresponding cell gave an efficiency of $14.2 \%$ [2]. As indicated before, a very similar PL signature is also observed, which overall is very promising for our material.

\section{Conclusion}

In this work, we report on a fabrication process of CIGS for silicon/CIGS tandem solar cells, consisting in the electrodeposition of metallic precursors on (100) silicon, followed by a sulfur annealing. The precursors are prepared by first depositing a thin layer of $\mathrm{Ag}$ on the silicon's surface, which serves as a cathode for the electrodeposition processes independently of the properties of the silicon substrate. This is highly suitable for replacing the silicon wafer by a complete solar cell in the future. After $\mathrm{Ag}$ deposition, $\mathrm{Cu}$, In and Ga are sequentially electrodeposited. The electrodeposition process is very fast, the whole stack being deposited in less than three minutes, and produces adherent, dense and smooth $\mathrm{Cu} / \mathrm{In} / \mathrm{Ga}$ layers on $20 \mathrm{~cm}^{2}$ silicon substrates. Conversion of the layers to AgCIGSu was performed in a short time scale of $10 \mathrm{~min}$ without optimization of process time. After optimization of the precursors composition, a sulfurized film with a measured composition of $(\mathrm{Cu}+\mathrm{Ag}) /(\mathrm{In}+\mathrm{Ga})=0.95$ and $\mathrm{Ga} /(\mathrm{In}+$ $\mathrm{Ga})=0.3$ was achieved. The layer presents very promising adhesion and density, and EDS mapping and GDOES analyses display the formation of two layers, the top one being indium-rich and the bottom being gallium rich. XRD and PL measurements confirmed the presence of these two phases. The strong similarity between this material and the CIGS reported in [3] in terms of bi-layer structure, composition and PL and XRD signatures indicate that our material is compatible with high efficiency widebandgap solar cells, making it a strong achievement on the way towards monolithic tandem Si/CIGS solar cells. Furthermore, the high deposition rates and short global time of our process offers a great compatibility with industry high-throughput requirements for low cost processing of new generation silicon tandem cells.

This project has been supported by the French Government in the frame of the program of investment for the future (Programme d'Investissement d'Avenir - ANR-IEED-002-01). The authors would like to acknowledge the help of their group members at IPVF, with special thanks to Sophie Gaillard for substrates etching.

\section{Author contribution statement}

A. C. designed and performed the experiments. He also performed part of the characterization and its interpretation, and wrote the manuscript with input from all authors. D. C. and B. Z. performed part of the characterization and aided in its analysis and interpretation. A. R. contributed to the experiments. A. T. and N. B. contributed to the interpretation of the XRD and PL data and discussions on pure sulfide CIGS layers. D. L. conceived the original idea and supervised the project.

\section{References}

1. H. Hiroi, Y. Iwata, S. Adachi, H. Sugimoto, A. Yamada, IEEE J. Photovoltaics 6, 760 (2016)

2. H. Sugimoto, H. Hiroi, Y. Iwata, A. Yamada, Recent progress in high efficiency pure sulfide CIGS solar cells, in 27th International Photovoltaic Science and Engineering Conference, 2017

3. N. Barreau, A. Thomere, High efficiency solar cell based on $\mathrm{Cu}(\mathrm{In}, \mathrm{Ga}) \mathrm{S}_{2}$ thin film grown by 3 -stage process, in 47 th IEEE Photovoltaic Specialists Conference, 2020 (to be published)

4. A. Thomere, C. Guillot-Deudon, M.T. Caldes, R. Bodeux, N. Barreau, S. Jobic, A. Lafond, Thin Solid Films 665, 46 (2018)

5. M. Edoff, T. Jarmar, N.S. Nilsson, E. Wallin, D. Högström, O. Stolt, O. Lundberg, W. Shafarman, L. Stolt, IEEE J. Photovoltaics 7, 1789 (2017)

6. J. Keller, K.V. Sopiha, O. Stolt, L. Stolt, C. Persson, J.J.S. Scragg, T. Törndahl, M. Edoff, Prog. Photovoltaics Res. Appl. 28, 237 (2020)

7. M. Richards, MiaSolé achieves flexible substrate thin-film solar cell efficiency of 20.56 percent, MiaSolé In the News 2019, http://miasole.com/

8. K. Kim, J. Gwak, S.K. Ahn, Y.-J. Eo, J. H. Park, J.-S. Cho, M.G. Kang, H.-E. Song, J.H. Yun, Sol. Energy 145, 52 (2017)

9. A.R. Jeong, S.B. Choi, W.M. Kim, J.-K. Park, J. Choi, I. Kim, J.-H. Jeong, Sci. Rep. 7, 15723 (2017)

10. A. Hajijafarassar, F. Martinho, F. Stulen, S. Grini, S. LópezMariño, M. Espíndola-Rodríguez, M. Döbeli, S. Canulescu, E. Stamate, M. Gansukh, S. Engberg, A. Crovetto, L. Vines, J. Schou, O. Hansen, Sol. Energy Mater. Sol. Cells 207, 110334 (2020)

11. A. Fave, J.-F. Lelièvre, T. Gallet, Q. Su, M. Lemiti, Energy Procedia 124, 577 (2017)

12. M. Nakamura, K. Yamaguchi, Y. Kimoto, Y. Yasaki, T. Kato, H. Sugimoto, IEEE J. Photovoltaics 9, 1863 (2019)

13. D. Lincot, J.F. Guillemoles, S. Taunier, D. Guimard, J. SicxKurdi, A. Chaumont, O. Roussel, O. Ramdani, C. Hubert, J. P. Fauvarque, N. Bodereau, L. Parissi, P. Panheleux, P. Fanouillere, N. Naghavi, P.P. Grand, M. Benfarah, P. Mogensen, O. Kerrec, Sol. Energy 77, 725 (2004)

14. C. Broussillo, C. Viscogliosi, A. Rogee, S. Angle, P.P. Grand, S. Bodnar, C. Debauche, J.L. Allary, B. Bertrand, C. Guillou, L. Parissi, S. Coletti, in 42nd IEEE Photovoltaic Specialists Conference, 2015, pp. 1-5

15. L. Deligianni, L. Romankiw, D. Lincot, P.-P. Grand, From the lab to scaling-up thin film solar absorbers: from discovery to product, in Electrochemical Engineering, edited by M. Koper, P.N. Bartlett, R.C. Alkire (Wiley, 2018), pp. $75-128$

16. H. Saïdi, C. Ben Alaya, M. F. Boujmil, B. Durand, J.L. Lazzari, M. Bouaïcha, Curr. Appl. Phys. 20, 29 (2020) 
17. J.D. Fields, Md.I. Ahmad, V.L. Pool, J. Yu, D.G. Van Campen, P.A. Parilla, M.F. Toney, M.F.A.M. van Hest, Nat. Commun. 7, 11143 (2016)

18. F. Oliva, Modélisation, caractérisation et optimisation des procédés de traitements thermiques pour la formation d'absorbeurs CIGS, doctoral dissertation, École Nationale Supérieure des Mines de Saint-Étienne, 2014
19. A. Thomere, Absorbeurs chalcogénures à grand gap $\sim 1,7 \mathrm{eV}$ pour la réalisation de cellules solaires en couches minces, doctoral dissertation, Université de Nantes, 2020

20. S. Kim, T. Nagai, H. Tampo, S. Ishizuka, H. Shibata, Prog. Photovoltaics Res. Appl. 28, 816 (2020)

21. H. Hiroi, Y. Iwata, H. Sugimoto, A. Yamada, IEEE J. Photovoltaics 6, 1630 (2016)

Cite this article as: Alexandre Crossay, Davide Cammilleri, Angelica Thomere, Bienlo Zerbo, Amelle Rebai, Nicolas Barreau, Daniel Lincot, Elaboration of wide bandgap CIGS on silicon by electrodeposition of stacked metal precursors and sulfur annealing for tandem solar cell applications, EPJ Photovoltaics 11, 11 (2020) 